\title{
Cellular Retinoic Acid-Binding Protein 1
}

National Cancer Institute

\section{Source}

National Cancer Institute. Cellular Retinoic Acid-Binding Protein 1. NCI Thesaurus. Code C97198.

Cellular retinoic acid-binding protein $1(137 \mathrm{aa}, \sim 16 \mathrm{kDa}$ ) is encoded by the human CRABP1 gene. This protein is involved in the regulation of retinoic acid receptor binding. 